\title{
THE EFFECTS OF TOTAL STARVATION UPON THE LEVELS OF CIRCULATING GLUCAGON AND INSULIN IN MAN*
}

\author{
By ROGER H. UNGER, ANNA M. EISENTRAUT, AND LEONARD L. MADISON \\ WITH THE TECHNICAL ASSISTANCE OF KATHRYN R. SIMS AND NANCY WHISSEN \\ (From the Department of Medicine, Veterans Administration Hospital, and The University \\ of Texas Southwestern Medical School, Dallas, Tex.)
}

(Submitted for publication January 18, 1963; accepted February 28, 1963)

Although the precise effects of starvation upon the function of the alpha and beta cells of the islets of Langerhans are unknown, there is reason to suspect that they are profound. In dogs, for example, severe glucose need caused by insulininduced hypoglycemia $(1,2)$ and phlorizin-induced hypoglycemia (2) is associated with a marked increase in glucagon secretion. Furthermore, it has been demonstrated that, in starved rats, the extractable insulin of the pancreas is reduced (3) ; this leads to the concept that the impaired glucose tolerance of starvation may, in large part, be the result of reduced insulin secretion.

A more complete understanding of the influence of glucose deprivation upon the function of the islet cells would clarify their role in the regulation of blood glucose disposition and homeostasis in health and in disease. Recently introduced immunochemical methods for the measurement of insulin $(4,5)$, and of glucagon $(6,7)$, made possible the following studies designed to determine the effect of total starvation upon the blood levels of these hormones in man.

\section{METHODS AND MATERIALS}

Glucagon assay. In order to enhance the sensitivity for measurement of endogenous glucagon in human serum, certain modifications of methods previously described (7) were introduced. These changes were found to be necessary, not only because of the lower concentrations of glucagon present in posthepatic blood as compared with that of the pancreatic venous effluent, obviously inaccessible in human studies, but also because of the nonspecific effects of human serum in high concentration upon the chromatographic behavior of glucagon- $\mathrm{I}^{131}$. Sensitivity was increased by reducing the trace amounts of glucagon- $\mathrm{I}^{132}$ used in the system in relation to the quantity of unknown. The quantities of human serum

* This paper was presented in part before the American Society for Clinical Investigation, Atlantic City, N. J., April, 1962. This study was supported by U. S. Public Health Service grants A-2700 and A-4236. employed resulted in a decreased affinity of glucagon- $\mathrm{I}^{181}$ for the chromatography paper, with up to $40 \%$ of the radioactivity migrating towards the protein area in the absence of antiserum. When $\mathrm{Na}_{2} \mathrm{SO}_{4}$ precipitation was used instead of chromatography to separate antibodybound and free glucagon- $\mathrm{I}^{131}$, nonspecific precipitation of radioactivity in the absence of antiserum was reduced to less than $6 \%$. This method, first reported by Grodsky and Forsham for the insulin assay (8), was subsequently shown by Grodsky, Hayashida, Peng, and Geschwind (9) to be adaptable for the glucagon assay.

The modified glucagon assay, to be described elsewhere in greater detail, was carried out as follows. Antiserum, $1 \mathrm{ml}$, was incubated at $25^{\circ} \mathrm{C}$ for 1 hour with $1 \mathrm{ml}$ of a standard glucagon solution, 0 to $2,000 \mu \mu \mathrm{g}$ per $\mathrm{ml}$ in $2 \%$ albumin, or of an unknown solution (serum), and approximately $50 \mu \mu \mathrm{g}$ of glucagon- $\mathrm{I}^{131}$ in $0.1 \mathrm{ml}$ was added. The mixture was incubated for 3 days at $4^{\circ} \mathrm{C}$. Total radioactivity in each sample was then counted in a welltype scintillation counter. Two $\mathrm{ml}$ of human plasma was then added to tubes which contained a glucagon standard solution, and $2 \mathrm{ml}$ of $2 \%$ albumin was added to tubes containing human serum. Immediately thereafter, $4.1 \mathrm{ml}$ of $30 \% \mathrm{Na}_{2} \mathrm{SO}_{4}$ was added with constant stirring, and after thorough mixing and 15 minutes of standing at room temperature, the mixture was centrifuged for 20 minutes at $2,000 \mathrm{rpm}$. The supernatant fluid was removed, and $4 \mathrm{ml}$ of $15 \% \quad \mathrm{Na}_{2} \mathrm{SO}_{4}$ was added, mixed thoroughly, and again centrifuged as before. ${ }^{1}$ After discarding the supernatant fluid, the precipitate was redissolved in distilled water to its original $2.1-\mathrm{ml}$ vol, and again counted to determine the antibody-bound glucagon$I^{131}$. The percentage of bound glucagon- $I^{131}$ was then determined and corrected for nonspecific glucagon- $\mathrm{I}^{131}$ binding by the method of Yalow and Berson (5) on the basis of the $\mathrm{Na}_{2} \mathrm{SO}_{4}$ precipitable radioactivity when nonimmune rabbit serum was substituted for rabbit antiglucagon antiserum in the reaction mixture. In these studies, this never exceeded $6 \%$.

The percentage of precipitated glucagon- $\mathrm{I}^{131}$ in the standard solutions was plotted as a function of its glucagon concentration, and gave consistently reproducible

1 This "wash" removed from the precipitate approximately 8 to $15 \%$ of the radioactivity, considered to be predominantly free, coprecipitated glucagon- $\mathrm{I}^{131}$. Subsequent washes were found to remove only an additional $2 \%$ or less and were, therefore, abandoned. 


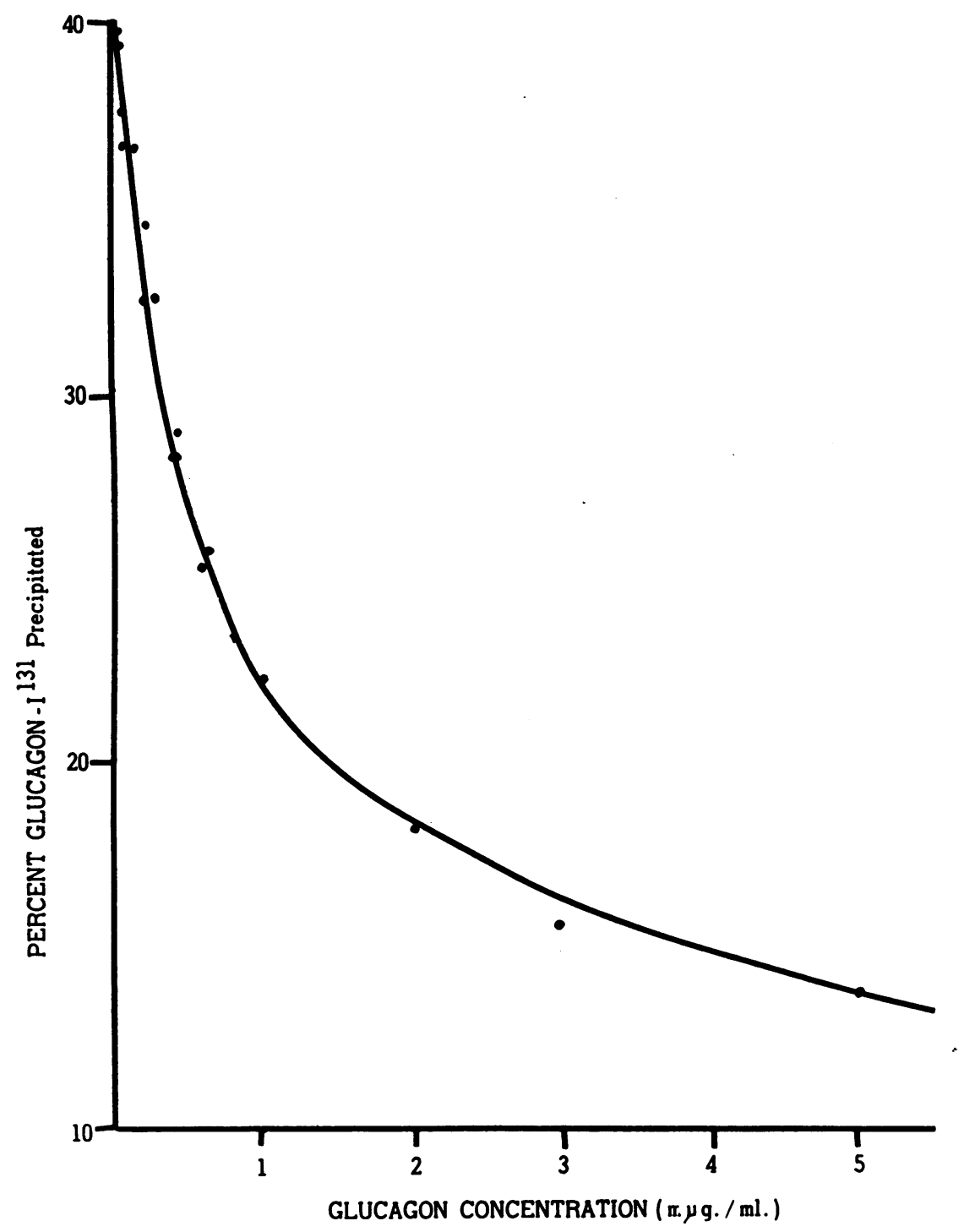

Fig. 1. Standard CURve. Percentage of glucagon- $\mathrm{I}^{131}$ precipitated is plotted as a function of glucagon concentration.

dose-response curves, one of which appears in Figure 1. All unknowns were measured in duplicate. The standard error of the method in human serum, calculated from 116 available replicate determinations of glucagon in human serum, including those to be presented here, was $\pm 13.4 \%$.

The term "micromicrogram equivalent" ( $\mu \mu \mathrm{gEq})$ was employed as the unit of endogenous glucagon in order to indicate that these results should not necessarily be considered as quantitative. Doubt in this respect stems from the possible immunologic dissimilarity between endogenous human glucagon of the unknown samples and the beef-pork glucagon in the standard solutions. In addition, the human serum in the reaction mixture results in greater damage and degradation of glucagon- $\mathrm{I}^{131}$ than does the $2 \%$ albumin solution used in making the standard glucagon solutions, introducing an additional disparity between the unknown and the standard samples.

Blood samples for immunoassay were drawn from the antecubital vein into sterile tubes and were allowed to clot at $6^{\circ}$ to $8^{\circ} \mathrm{C}$. After centrifugation at $4^{\circ} \mathrm{C}$, the serum was removed and kept frozen until the time for glucagon and insulin assay.

Insulin assay. Insulin concentration was determined by the method of Berson and Yalow (5). However, chromatographic rather than chromatoelectrophoretic separation of bound and free insulin- $\mathrm{I}^{131}$ was employed, and strips were bisected and counted in a well-type gamma scintillation counter.

Blood glucose concentration was determined by the 
method of Hoffman, by using a Technicon Autoanalyzer (10), and FFA concentration by the Trout, Estes, and Friedberg modification (11) of the method of Dole (12).

\section{RESULTS}

Recovery of exogenous glucagon added to human serum. In order to determine the ability of the modified assay system to detect small increments in the glucagon concentration of human serum, the concentration of endogenous glucagon was measured in the serum of six fasting subjects. Beef-pork glucagon, and in one instance human glucagon, ${ }^{2}$ was then added so as to raise the glucagon concentration by $250,500,1,000$, and 2,000 $\mu \mu \mathrm{g}$ per $\mathrm{ml}$, and the sera were then assayed. The initial endogenous glucagon concentration was subtracted from the total glucagon concentration, and the differences, or recovery values, are recorded in Table I.

The results indicate that the modified assay is capable of detecting increments in glucagon concentration of as little as $250 \mu \mu \mathrm{g}$ per ml. Without exception, each difference in glucagon concentration measured in the recovery of the varying quantities of beef-pork and human glucagon was more than twice the standard error of the method.

Relatively good quantitative correlation in the concentration range of less than $1,000 \mu \mu \mathrm{g}$ per $\mathrm{ml}$ between the amount of glucagon added and that recovered indicates that human serum has neither an inhibitory nor an augmentative effect upon the

2 A solution of crude acid-ethanol extract of human pancreas was assayed for glucagon content against beefpork glucagon standard solutions, and the appropriate dilution were added to serum samples.
TABLE I

Recovery of exogenous glucagon added to human serum (total glucagon minus endogenous glucagon)

\begin{tabular}{|c|c|c|c|c|c|}
\hline \multirow{2}{*}{$\begin{array}{c}\text { Serum } \\
\text { no. }\end{array}$} & \multicolumn{5}{|c|}{ Amount of glucagon added } \\
\hline & 0* & 250 & 500 & 1,000 & 2,000 \\
\hline & \multicolumn{5}{|c|}{$\mu \mu g E q / m l$} \\
\hline 1 & 325 & 250 & 475 & 900 & 1,525 \\
\hline 2 & 650 & 175 & 300 & 600 & 1,150 \\
\hline 3 & 525 & 225 & 475 & 925 & 1,800 \\
\hline 4 & 225 & 300 & 625 & 1,200 & 2,175 \\
\hline 5 & 475 & 250 & 475 & 975 & 2,075 \\
\hline $6 \dagger$ & 200 & 250 & 525 & 1,150 & 2,550 \\
\hline
\end{tabular}

* Values represent endogenous glucagon in micromicrogram equivalents per milliliter.

$\dagger$ Human rather than beef-pork glucagon was added to serum no. 6 ; results are in micromicrogram equivalents per milliliter.

assay. Correlation becomes poor above 1,000 $\mu \mu \mathrm{g}$ per $\mathrm{ml}$, as the dose-response curve (Figure 1) begins to level off.

Effects of total starvation upon glucagon concentration. Eight young male volunteers, one of whom was mildly diabetic, ingested no food or beverages other than water and unsweetened black coffee for 3 days. Blood was drawn daily at 8 a.m. before and during the starvation period, and the concentration of glucose and glucagon was determined. In five subjects, including the mild diabetic, the FFA concentration was measured daily.

All eight subjects lost weight, from 2.7 to 5.2 $\mathrm{kg}$, during the 3 days of starvation. All of the five subjects studied exhibited a striking increase in the level of FFA; the FFA concentration, which had averaged $500 \mu \mathrm{Eq}$ per L prior to star-

TABLE II

Glucagon concentration during starvation

\begin{tabular}{|c|c|c|c|c|c|c|c|c|c|c|c|c|}
\hline \multirow{2}{*}{$\begin{array}{c}\text { Subject } \\
\text { no. }\end{array}$} & \multicolumn{3}{|c|}{ Day 0} & \multicolumn{3}{|c|}{ Day 1} & \multicolumn{3}{|c|}{ Day 2} & \multicolumn{3}{|c|}{ Day 3} \\
\hline & Glucose & FFA & Glucagon & Glucose & FFA & Glucagon & Glucose & FFA & Glucagon & Glucose & FFA & Glucagon \\
\hline & $\stackrel{\mathrm{mg} /}{100 \mathrm{ml}}$ & $\mu E q / L$ & $\underset{m l}{\mu \mu g E q /}$ & $\begin{array}{c}\mathrm{mg} / \\
100 \mathrm{ml}\end{array}$ & $\mu E q / L$ & $\underset{m l}{\mu \mu g E q /}$ & $\begin{array}{c}\mathrm{mg} / \\
100 \mathrm{ml}\end{array}$ & $\mu E q / L$ & $\underset{m l}{\mu \mu g E q}$ & $\begin{array}{c}m g / \\
100 ~ m l\end{array}$ & $\mu E q / L$ & $\underset{m l}{\mu \mu g E q /}$ \\
\hline 1 & 110 & 326 & 0 & 85 & 943 & o & 70 & 1,068 & 300 & 65 & 1,865 & 850 \\
\hline 2 & 66 & & 415 & 42 & & 680 & 42 & & 725 & 37 & & 875 \\
\hline 3 & $130+$ & & 50 & 75 & & 50 & 60 & & 400 & 52 & & 660 \\
\hline 4 & 75 & & 650 & 80 & & 770 & 74 & & 1,250 & 76 & & 1,225 \\
\hline 5 & 75 & 652 & 470 & 70 & 1,438 & 930 & 60 & 1,418 & 700 & 44 & 1,786 & 1,350 \\
\hline 6 & $116 \dagger$ & 424 & 350 & 75 & 1,314 & 425 & 60 & 1,233 & 470 & 55 & 1,567 & 785 \\
\hline 7 & & 409 & 400 & 65 & 1,388 & 100 & 58 & 1,340 & 500 & 60 & 1,309 & 700 \\
\hline $8^{*}$ & 112 & 689 & $\mathbf{0}$ & 77 & 1,408 & o & 55 & 1,393 & 380 & 40 & 1,736 & 700 \\
\hline Mean & 98 & 500 & 292 & 71 & 1,298 & 369 & 50 & 1,290 & 591 & 54 & 1,653 & 893 \\
\hline
\end{tabular}

* Mild diabetic.

† Not fasting. 


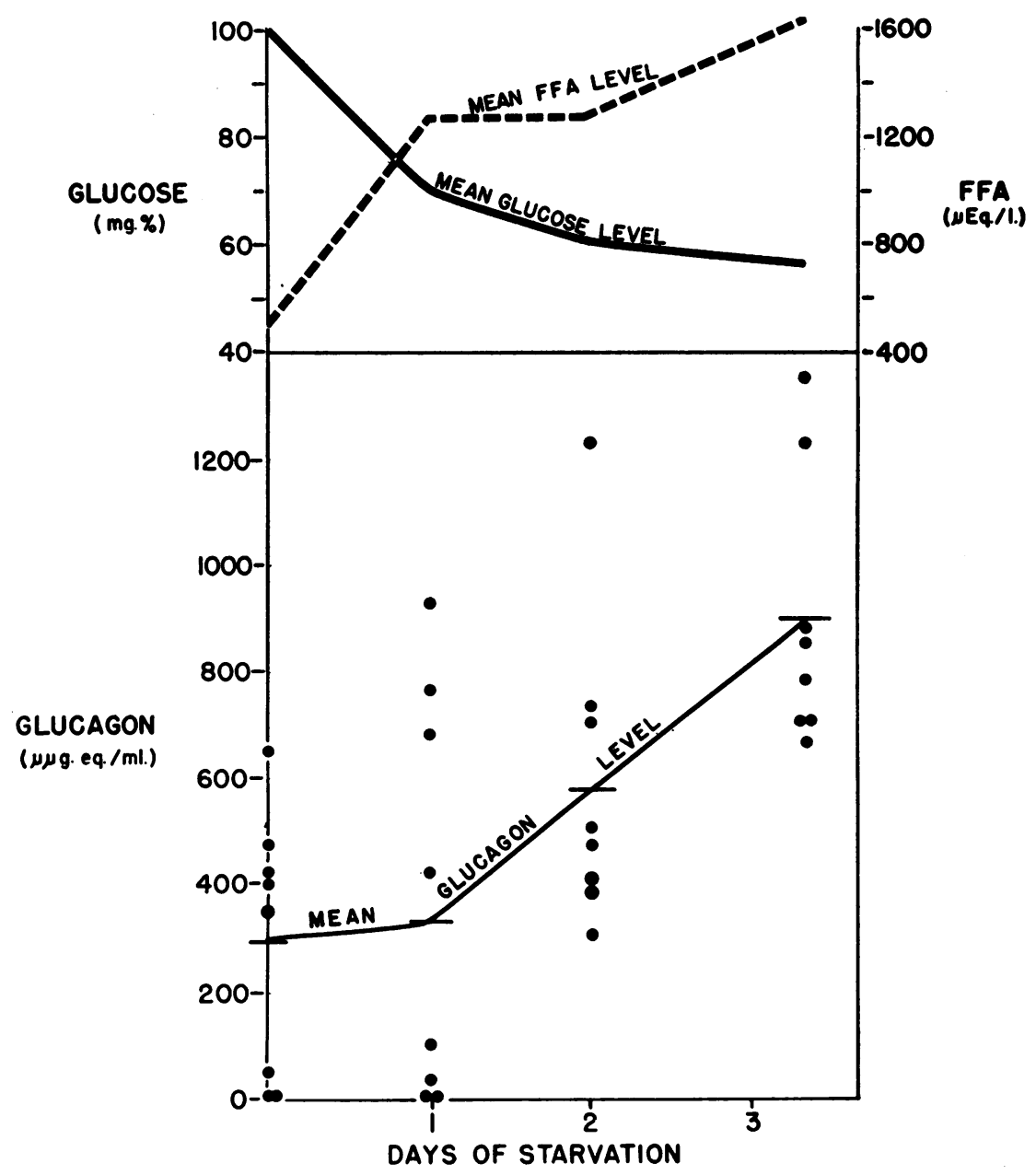

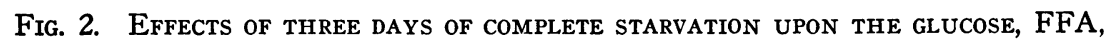
AND GLUCAGON LEVELs. Glucagon concentration, which averaged $292 \mu \mu \mathrm{gEq}$ per ml before the fast, rose significantly in all subjects to a mean level of $893 \mu \mu \mathrm{gEq}$ per $\mathrm{ml}$ after 3 days of starvation $(p<0.01)$.

vation, rose to a mean level of $1,653 \mu \mathrm{Eq}$ per $\mathrm{L}$ after 3 days of starvation. Glucose concentration declined progressively during starvation to a mean level of $54.0 \mathrm{mg}$ per $100 \mathrm{ml}$ at the third day, and in three individuals, values of $45 \mathrm{mg}$ per $100 \mathrm{ml}$ or less were observed during the fast.

Glucagon concentration, which had averaged 292 $\mu \mu \mathrm{gEq}$ per $\mathrm{ml}$ before starvation, failed to change significantly during the first 24 hours; however, at the end of 48 hours there was a statistically significant increase in glucagon concentration, which rose further to a mean level of $893 \mu \mu \mathrm{gEq}$ per ml at the end of day 3 of starvation $(p<0.01)$. The results are summarized in Table II and Figure 2.

Effects of glucose refeeding after starvation on glucagon concentration. At the end of day 3 of total starvation, all eight subjects were given 100 $\mathrm{g}$ of glucose by mouth, and hourly blood samples were obtained for up to 3 hours thereafter. The results are shown in Figure 3.

Glucose tolerance was strikingly impaired in all subjects, all but one of whom had previously exhibited normal tolerance when on their usual diet. The blood glucose concentration of the seven nondiabetic subjects averaged $210 \mathrm{mg}$ per $100 \mathrm{ml} 1$ hour after the ingestion of glucose, 250 $\mathrm{mg}$ per $100 \mathrm{ml} 2$ hours after, and $180 \mathrm{mg}$ per 100 $\mathrm{ml}$ after 3 hours. In all of the five subjects in whom it was measured, the FFA level fell from a mean of $1,653 \mu \mathrm{Eq}$ per $\mathrm{L}$ at the end of the starva- 
tion period to $529 \mu \mathrm{Eq}$ per $\mathrm{L}$ within the 3-hour period after glucose ingestion.

Glucagon concentration declined substantially in five of the eight subjects, but measurements beyond the 1-hour specimen were made in only four persons. In all subjects, however, the level remained well above the prestarvation fasting glucagon concentration. Thus, while the ultimate return of the elevated glucagon levels to normal after refeeding may be assumed, the results suggest that the decline is not rapid and that hyperglucagonemia persists for at least the first 2 to 3 hours after refeeding.

Insulin levels during glucose loading after starvation. The impaired glucose tolerance that follows starvation, so-called "starvation diabetes," has commonly been ascribed to an inability of beta cells to respond adequately to hyperglycemia after a period of prolonged inactivity induced by carbohydrate deprivation. It seemed of interest, therefore, to compare the response of serum insulin levels to oral glucose loading in a similar group of five healthy young men before and after 3 days of total starvation.

Immediately before the 3-day starvation period, all five subjects exhibited a perfectly normal gluclose tolerance curve. After the ingestion of 100 $\mathrm{g}$ of glucose, the mean serum insulin level rose briskly in each subject, generally paralleling the blood sugar curve, from a fasting level of $34.6 \mu \mathrm{U}$ per $\mathrm{ml}$ to a peak level of $139.5 \mu \mathrm{U}$ per $\mathrm{ml} 40 \mathrm{~min}$ utes after glucose ingestion (Figure $4 \mathrm{~A}$ ). It declined rapidly thereafter, returning to a base-line level of $32.5 \mu \mathrm{U}$ per $\mathrm{ml}$ at the third hour.

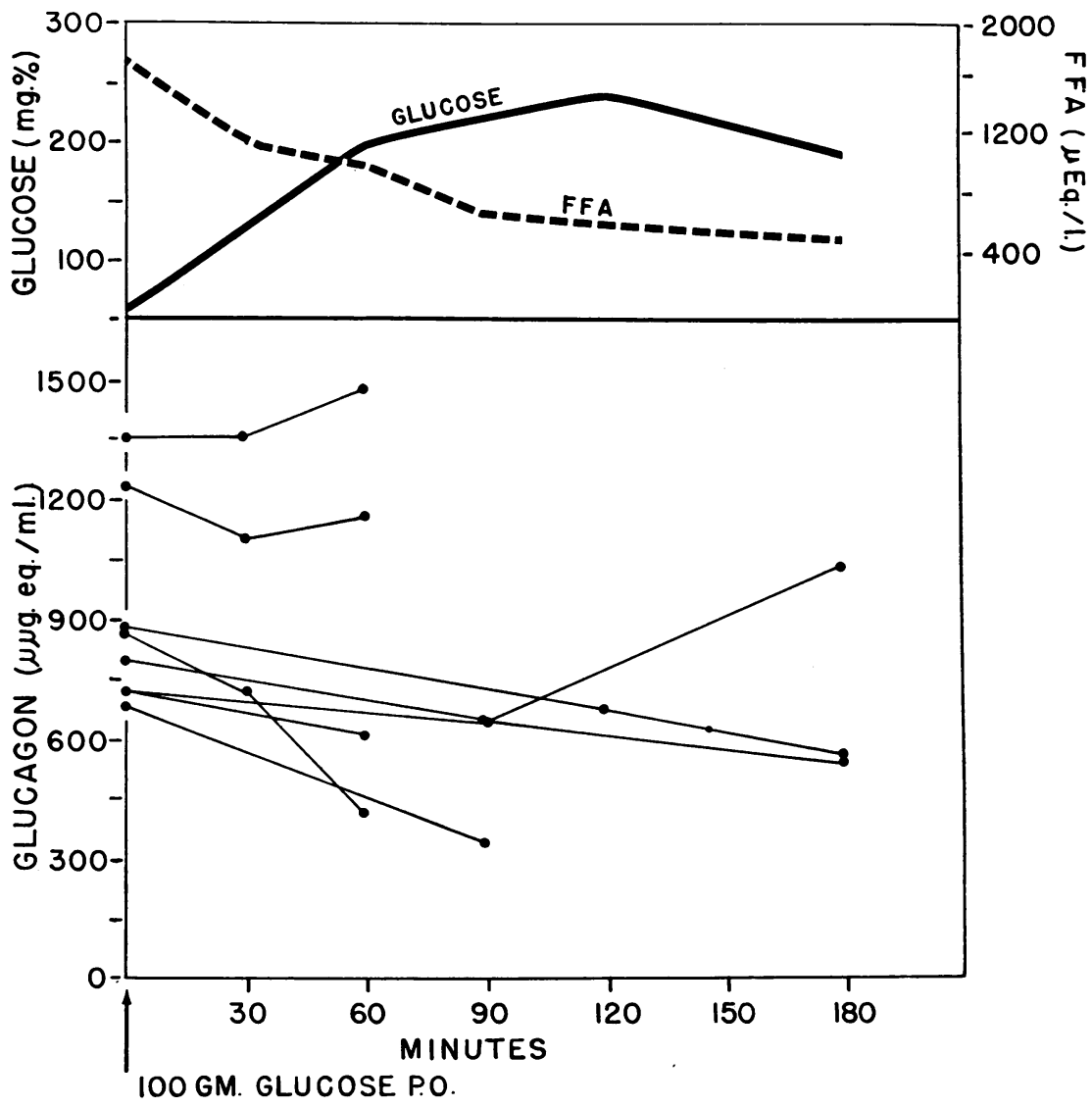

Fig. 3. Glucagon levels after glucose loading in starving subjects. After 3 days of total starvation, $100 \mathrm{~g}$ of glucose was given by mouth to each of the eight volunteers, and a strikingly abnormal oral glucose tolerance curve was exhibited in each. The FFA level declined rapidly during the 3 hours of the test. Glucagon concentration declined in five of the eight subjects, but did not reach prestarvation levels in any case during the period of observation. 


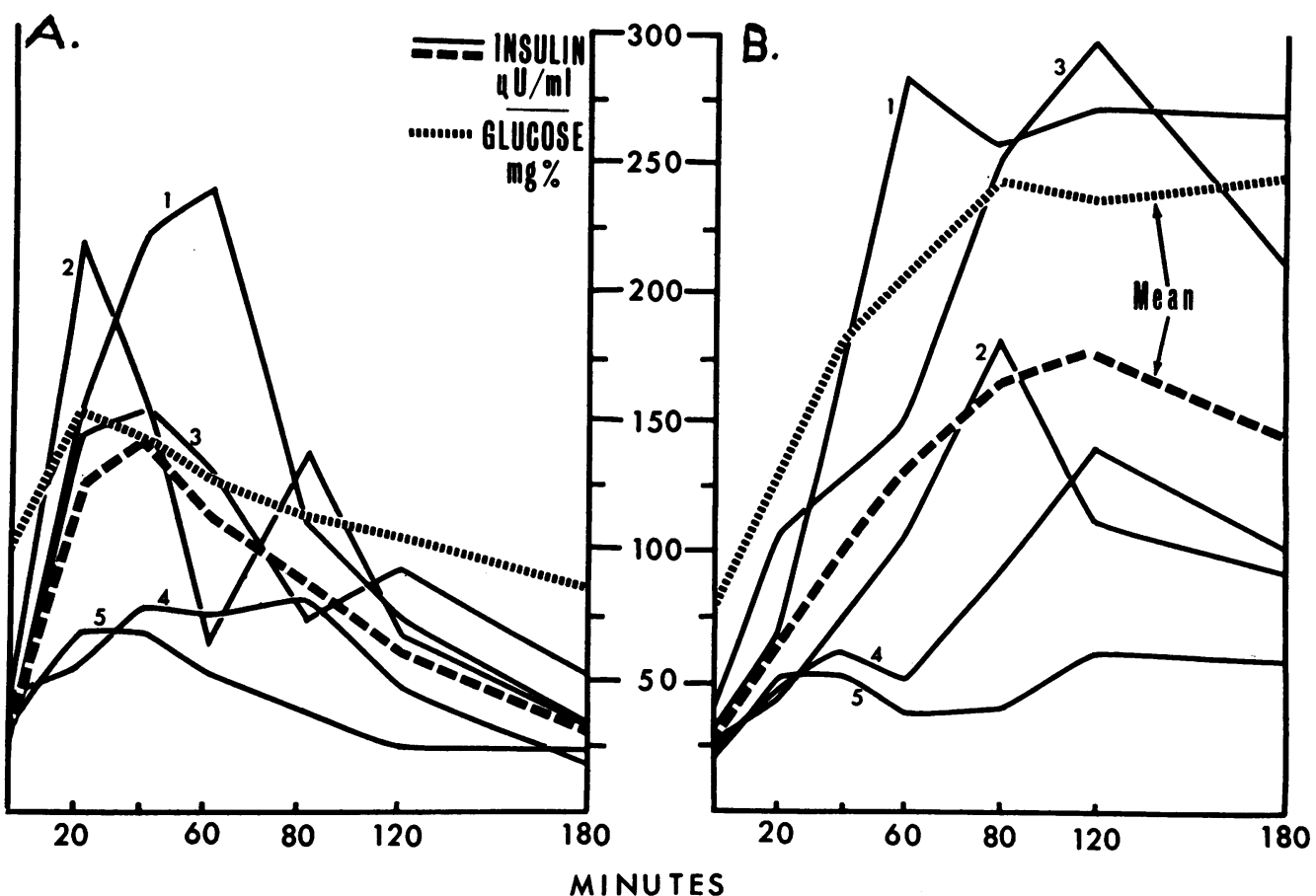

Fig. 4. Insulin concentrations after the ingestion of $100 \mathrm{~g}$ of glucose. A. Before starvation, the mean glucose curve, represented by the striated line, was normal in all five subjects. The mean insulin level, represented by the bar line, rose rapidly to a peak at 40 minutes and declined rapidly, returning to fasting levels within 180 minutes. The individual insulin levels are represented by the numbered thin lines. B. After 3 days of starvation, the glucose tolerance curve was markedly impaired in every subject. The response of the mean insulin concentration was also abnormal: 1) A striking delay in the initial rise occurred, the peak shifting from 40 to 120 minutes after glucose ingestion, and 2) hyperinsulinemia persisted for at least 180 minutes after glucose ingestion.

By contrast, after 3 days of total starvation, the glucose tolerance curve (Figure $4 \mathrm{~B}$ ) was markedly elevated in each of the five subjects, the mean blood glucose level averaging 203, 235, and 242 $\mathrm{mg}$ per $100 \mathrm{ml}$ at 1,2 , and 3 hours, respectively.
In every subject, the rate of rise in the serum insulin concentration during the first hour was slower than that exhibited during the prestarvation glucose-tolerance test, the mean insulin level reaching a peak of $176.3 \mu \mathrm{U}$ per $\mathrm{ml}$ at 120 minutes

TABLE III

Effects of starvation on serum insulin response to oral glucose loading (microunits per milliliter)

\begin{tabular}{|c|c|c|c|c|c|c|c|c|c|c|c|c|c|c|c|}
\hline \multirow{2}{*}{$\begin{array}{c}\text { Subject } \\
\text { no. }\end{array}$} & \multirow{2}{*}{$\begin{array}{l}\text { Minutes } \\
\text { after } \\
\text { glucose: }\end{array}$} & \multicolumn{7}{|c|}{ Before starvation } & \multicolumn{7}{|c|}{ After starvation } \\
\hline & & 0 & 20 & 40 & 60 & 90 & 120 & 180 & $\mathbf{0}$ & 20 & 40 & 60 & 90 & 120 & 180 \\
\hline 1 & $\begin{array}{l}\text { Insulin } \\
\text { Glucose }\end{array}$ & $\begin{array}{l}28 \\
93\end{array}$ & $\begin{array}{l}153 \\
160\end{array}$ & $\begin{array}{l}220 \\
189\end{array}$ & $\begin{array}{l}238 \\
151\end{array}$ & $\begin{array}{l}113 \\
100\end{array}$ & $\begin{array}{l}74 \\
86\end{array}$ & $\begin{array}{l}34 \\
69\end{array}$ & $\begin{array}{l}29 \\
77\end{array}$ & $\begin{array}{r}69 \\
139\end{array}$ & $\begin{array}{l}170 \\
221\end{array}$ & $\begin{array}{l}283.8 \\
271\end{array}$ & $\begin{array}{l}256.5 \\
289\end{array}$ & $\begin{array}{l}271.9 \\
283\end{array}$ & $\begin{array}{l}269.4 \\
258\end{array}$ \\
\hline 2 & $\begin{array}{l}\text { Insulin } \\
\text { Glucose }\end{array}$ & $\begin{array}{r}43 \\
102\end{array}$ & $\begin{array}{l}216 \\
147\end{array}$ & $\begin{array}{l}153 \\
100\end{array}$ & $\begin{array}{l}63 \\
84\end{array}$ & $\begin{array}{r}138 \\
.123\end{array}$ & $\begin{array}{r}66 \\
101\end{array}$ & $\begin{array}{l}34 \\
86\end{array}$ & $\begin{array}{l}28 \\
75\end{array}$ & $\begin{array}{r}44 \\
101\end{array}$ & $\begin{array}{r}75 \\
144\end{array}$ & $\begin{array}{l}105.6 \\
160\end{array}$ & $\begin{array}{l}181.3 \\
174\end{array}$ & $\begin{array}{l}111.9 \\
155\end{array}$ & $\begin{array}{l}92.5 \\
166\end{array}$ \\
\hline 3 & $\begin{array}{l}\text { Insulin } \\
\text { Glucose }\end{array}$ & $\begin{array}{r}29 \\
100\end{array}$ & $\begin{array}{l}141 \\
146\end{array}$ & $\begin{array}{l}153 \\
136\end{array}$ & $\begin{array}{l}129 \\
142\end{array}$ & $\begin{array}{r}74 \\
104\end{array}$ & $\begin{array}{r}94 \\
113\end{array}$ & $\begin{array}{r}52 \\
102\end{array}$ & $\begin{array}{l}43 \\
76\end{array}$ & $\begin{array}{l}907 \\
147\end{array}$ & $\begin{array}{l}125 \\
177\end{array}$ & $\begin{array}{l}148.8 \\
182\end{array}$ & $\begin{array}{l}252.5 \\
224\end{array}$ & $\begin{array}{l}296.9 \\
240\end{array}$ & 287.3 \\
\hline 4 & $\begin{array}{l}\text { Insulin } \\
\text { Glucose }\end{array}$ & $\begin{array}{r}43 \\
103\end{array}$ & $\begin{array}{r}54 \\
135\end{array}$ & $\begin{array}{r}79 \\
154\end{array}$ & $\begin{array}{r}73 \\
156\end{array}$ & $\begin{array}{r}80 \\
123\end{array}$ & $\begin{array}{r}46 \\
124\end{array}$ & $\begin{array}{l}19 \\
79\end{array}$ & $\begin{array}{l}25 \\
77\end{array}$ & $\begin{array}{r}46 \\
140\end{array}$ & $\begin{array}{c}61.3 \\
160\end{array}$ & $\begin{array}{r}50 \\
170\end{array}$ & $\begin{array}{l}93.8 \\
246\end{array}$ & $\begin{array}{l}140 \\
222\end{array}$ & $\begin{array}{l}100.6 \\
247\end{array}$ \\
\hline 5 & $\begin{array}{l}\text { Insulin } \\
\text { Glucose }\end{array}$ & $\begin{array}{r}32 \\
102\end{array}$ & $\begin{array}{r}69 \\
179\end{array}$ & $\begin{array}{r}68 \\
120\end{array}$ & $\begin{array}{l}51 \\
96\end{array}$ & $\begin{array}{r}39 \\
104\end{array}$ & $\begin{array}{l}23 \\
97\end{array}$ & $\begin{array}{l}24 \\
90\end{array}$ & $\begin{array}{l}20 \\
80\end{array}$ & $\begin{array}{r}51 \\
133\end{array}$ & $\begin{array}{l}52.5 \\
196\end{array}$ & $\begin{array}{c}38.1 \\
233\end{array}$ & $\begin{array}{l}38.4 \\
285\end{array}$ & $\begin{array}{l}60.6 \\
273\end{array}$ & $\begin{array}{r}58.8 \\
250\end{array}$ \\
\hline Mean & $\begin{array}{l}\text { Insulin } \\
\text { Glucose }\end{array}$ & $\begin{array}{c}34.6 \\
100\end{array}$ & $\begin{array}{l}126.7 \\
154\end{array}$ & $\begin{array}{l}139.5 \\
140\end{array}$ & $\begin{array}{l}110.8 \\
126\end{array}$ & $\begin{array}{l}88.6 \\
111\end{array}$ & $\begin{array}{l}60.7 \\
84\end{array}$ & 85.5 & ${ }_{77}^{28.9}$ & $\begin{array}{c}63.3 \\
132\end{array}$ & $\begin{array}{c}96.8 \\
180\end{array}$ & $\begin{array}{l}125.1 \\
203\end{array}$ & $\begin{array}{l}164.5 \\
244\end{array}$ & $\begin{array}{l}176.3 \\
235\end{array}$ & $\begin{array}{l}146.5 \\
242\end{array}$ \\
\hline
\end{tabular}


after glucose ingestion. A statistically significant difference $(p<0.05)$ between the prestarvation insulin level of $126 \mu \mathrm{U}$ per $\mathrm{ml}$ and the poststarvation level of $63.3 \mu \mathrm{U}$ per $\mathrm{ml}$ was noted at $20 \mathrm{~min}$ utes after glucose ingestion.

A second and equally striking abnormality in the pattern of response of the serum insulin level to glucose after starvation, observed in all five subjects, was a marked prolongation of glucoseinduced hyperinsulinemia. Before starvation, the mean insulin level returned to $32.5 \mu \mathrm{U}$ per $\mathrm{ml}$ within 3 hours, whereas after starvation, the mean 3-hour value was still at $146.5 \mu \mathrm{U}$ per $\mathrm{ml}$, a statistically significant difference $(p<0.05)$. The insulin level for each individual appeared in general to parallel the elevated blood glucose level.

The findings above are summarized in Table III and Figure 4.

DISCUSSION

The foregoing data provide the first measurements by a specific technic of circulating glucagon in man. They reveal a striking and uniform increase in serum glucagon concentration after the first 48 hours of total starvation both in the young nondiabetic males and in the mild, diet-controlled, diabetic subject. Similar results are said to have been obtained by means of a bioassay technic (14). The direct demonstration in dogs of an increase in glucagon secretion during acute and chronic hypoglycemia (2) suggests that the hyperglucagonemia noted during starvation was the consequence of an increase in glucagon secretion, rather than a decrease in glucagon disappearance. Those studies in dogs also revealed that substantial increases in glucagon concentration in the pancreatic venous effluent may be accompanied by only trivial rises in its concentration in the posthepatic venous blood, a consequence of the avidity with which glucagon is bound during its initial transhepatic circulation (2) ; it seems probable, therefore, that the actual rate and magnitude of the increase in glucagon secretion was far greater than these measurements in the posthepatic venous blood reveal.

It seems reasonable to assume that, with refeeding, the elevated glucagon concentration associated with starvation would, in time, inevitably return to normal. During the brief periods of measurement following glucose reloading in these starving subjects, a downward trend in glucagon concentration was observed in most subjects. Some degree of starvation hyperglucagonemia, however, persisted throughout at least the first half of the standard oral glucose-tolerance tests. In view of this, it might be suggested that the persisting hyperglucagonemia contributed to the diabetic contour of the oral glucose-tolerance curves, so-called "starvation diabetes," by preventing or limiting the decrease in hepatic glucose output which, under normal circumstances, follows the ingestion of glucose. Leonards and associates (15) have demonstrated that restriction of dietary carbohydrate alone does, in fact, abolish the effect of insulin upon hepatic glucose output; an excess of glucagon could account for this observation.

Profound alterations in the patterns of response of serum insulin concentration to glucose loading, however, were also shown to follow 3 days of total starvation. First, instead of the brisk rise that normally follows glucose ingestion, a marked delay in the rise of insulin concentration was observed in all subjects after starvation. This delay, reflected by a shift in the time of the peak of the mean insulin concentration from 40 to 120 minutes after glucose ingestion, is most plausibly ascribed to a diminished rate of insulin secretion, possibly the result of diminished insulin stores, shown by Best, Haist, and Ridout to follow prolonged fasting in the rat (3). The possibility that increased binding of insulin by the liver and by other tissues causes the lower insulin levels in the peripheral venous circulation immediately after glucose loading seems unlikely in view of studies in rats suggesting that first circulation binding by liver of insulin- ${ }^{131}$ injected into the portal vein of rats is reduced by starvation (16). However, a contributing factor, at least in the first 20 minutes, in this delay in insulin response may be a delay in the rise in blood sugar to levels required to stimulate insulin secretion. Whereas, before starvation, four of the five blood glucose values at 20 minutes after glucose exceeded $140 \mathrm{mg}$ per $100 \mathrm{ml}$, after starvation only one of five exceeded this level (Table III). The lag in hyperglycemia may be a result of contraction in the glucose pool during starvation. 
A second consistent and equally dramatic change in the pattern of insulin response to glucose loading was failure of the insulin level to return to normal as rapidly as before starvation. Although preliminary observations in dogs indicate that a delay, never exceeding $0.1 \%$ per minute, in the disappearance time of tracer doses, 1 $\mathrm{mU}$, of insulin- $\mathrm{I}^{131}$ acutely injected via a peripheral vein may occur in starving dogs (16), this relatively minor decrease in the rate of insulin disappearance would not account for the fourfold increase in the mean insulin concentration observed 180 minutes after glucose ingestion in this group of starving human subjects. In Subject 1 (Figure $4 \mathrm{~A}$ ), for example, the rapid decline in serum insulin concentration that occurred after 60 minutes closely resembles the normal disappearance curve of acutely injected insulin- $\mathrm{I}^{131}$ (17), implying an abrupt and virtually complete shutdown in insulin secretion at a time when the blood sugar level had fallen to $151 \mathrm{mg}$ per $100 \mathrm{ml}$ (Table III). After starvation, however, (Figure $4 \mathrm{~B})$, Subject 1 exhibited a plateau in the insulin concentration from 60 to 180 minutes after glucose ingestion, at a time when his blood sugar level remained above $250 \mathrm{mg}$ per $100 \mathrm{ml}$. Unless insulin disappearance had virtually ceased, this plateau can be accounted for only by the persistance of a high rate of insulin secretion which, in this case, was equal to the rate of insulin disappearance. It seems very likely that, in all subjects after starvation, insulin secretion continues during the last 90 minutes of the glucose tolerance test, a period in which, under normal circumstances, it virtually ceased.

The persistent hyperglycemia of the poststarvation glucose-tolerance test provides ample stimulus for the continued secretion of insulin. One may then wonder why, during a period of abundance of circulating insulin lasting at least 90 minutes, the abnormally high levels of blood sugar persist. The answer to this is not provided by this study, which does, however, rule out an absolute insulin deficiency in this phase of the glucose-tolerance test. A number of possible explanations deserve consideration. 1) Although the insulin levels in starvation are inappropriately high for the last half of an oral glucose-tolerance test, they are abnormally low in relation to the exag- gerated hyperglycemic stimulus, which in turn may have resulted from the delayed insulin release observed during the first 40 minutes of the test. 2) The circulating insulin, although immunologically reactive, is biologically defective; somewhat against this concept, at least in the case of fat cells, is the apparent effectiveness of the insulin in lowering the markedly elevated levels of FFA at a time when glucose concentration continues to remain elevated. 3) Excessive insulin destruction induced by starvation reduces the effectiveness of insulin; this, too, seems possible, since Mirsky and Perisutti have shown that insulinase activity in rat liver slices rises during starvation (18). 4) Starvation, by some mechanism, induces a marked delay in disappearance of endogenous human insulin from the circulation, with resulting tissue deprivation of insulin, thereby accounting for both hyperinsulinemia and hyperglycemia.

Additional explanations for these findings include 5) the possibility of some type of starvationinduced antagonism to insulin (19), as yet unidentified, and 6) as mentioned previously, the possibility that the coexisting hyperglucagonemia modifies the effect of insulin in reducing the hepatic glucose output, either directly by its glycogenolytic or gluconeogenic actions, or by reducing hepatic binding of insulin, as Skinner and Madison demonstrated in rats (20). Finally, 7) a diminished effect of insulin could be attributed to starvation-induced changes in various enzyme systems (21).

The similarity between the patterns of insulin response to glucose loading in starvation and those of mild maturity-onset diabetes, as reported by Yalow and Berson (5), raises the hope that further understanding of the mechanism of defects induced by starvation may shed additional light on the pathogenesis of mild adult diabetes.

These studies of human glucagon are in accord with earlier studies in dogs $(1,2)$ which indicated that an increase in glucagon secretion is directly or indirectly provoked by lack of glucose. From the teleologic standpoint, this suggests that glucagon, through its glycogenolytic action and, perhaps of greater importance in starvation, through its gluconeogenic action (22-24), is one of the means by which the flow of glucose to 
vital, glucose-dependent tissues, such as the brain, is maintained in time of glucose unavailability.

\section{SUMMARY}

The level of circulating glucagon and insulin has been measured in young male volunteers during 3 days of complete starvation and subsequent glucose refeeding. Glucagon concentration rose after 48 hours to a mean value which, at 72 hours, was three times the prestarvation level.

After 3 days of starvation, the ingestion of 100 $\mathrm{g}$ of glucose invariably resulted in a "diabetic" tolerance curve. Glucagon concentration declined to a variable degree in most subjects, but remained well above the normal prestarvation level for most, if not all, of the 3-hour test. The mean insulin level, which before starvation rose rapidly to a peak 40 minutes after glucose ingestion and declined rapidly thereafter, rose more slowly to a peak at 120 minutes and remained well elevated throughout the third hour.

Possible explanations for these findings are reviewed, and their implications in respect to the regulation of glucose disposition are considered.

\section{REFERENCES}

1. Foà, P. P., G. Galansino, and G. Pozza. Glucagon, a second pancreatic hormone. Recent Progr. Hormone Res. 1957, 13, 473.

2. Unger, R. H., A. M. Eisentraut, M. S. McCall, and L. L. Madison. Measurements of endogenous glucagon in plasma and the influence of blood glucose concentration upon its secretion. J. clin. Invest. 1962, 41, 682.

3. Best, C. H., R. E. Haist, and J. H. Ridout. Diet and the insulin content of pancreas. J. Physiol. (Lond.) 1939, 97, 107.

4. Berson, S. A., and R. S. Yalow. Isotopic tracers in the study of diabetes. Advanc. biol. med. Phys. 1958, 6, 349.

5. Yalow, R. S., and S. A. Berson. Immunoassay of endogenous plasma insulin in man. J. clin. Invest. 1960, 39, 1157.

6. Unger, R. H., A. M. Eisentraut, M. S. McCall, S. Keller, H. C. Lanz, and L. L. Madison. Glucagon antibodies and their use for an immunoassay for glucagon. Proc. Soc. exp. Biol. (N. Y.) 1959, $102,621$.

7. Unger, R. H., A. M. Eisentraut, M. S. McCall, and L. L. Madison. Glucagon antibodies and an immunoassay for glucagon. J. clin. Invest. 1961, 40, 1280.
8. Grodsky, G. M., and P. H. Forsham. An immunochemical assay of total extractable insulin in man. J. clin. Invest. 1960, 39, 1070.

9. Grodsky, G. M., T. Hayashida, C. T. Peng, and I. I. Geschwind. Production of glucagon antibodies and their role in metabolism and immunoassay of glucagon. Proc. Soc. exp. Biol. (N. Y.) 1961, 107, 491.

10. Hoffman, W. S. Rapid photoelectric method for the determination of glucose in blood and urine. $\mathrm{J}$. biol. Chem. 1937, 120, 51.

11. Trout, D. L., E. H. Estes, Jr., and S. J. Friedberg. Titration of free fatty acids of plasma: a study of current methods and a new modification. J. Lipid Res. 1960, 1, 199.

12. Dole, V. P. A relation between the non-esterified fatty acids in plasma and the metabolism of glucose. J. clin. Invest. $156,35,150$.

13. Berson, S. A., R. S. Yalow, and B. W. Volk. In vivo and in vitro metabolism of insulin- $\mathrm{I}^{181}$ and glucagon- ${ }^{181}$ in normal and cortisone-treated rabbits. J. Lab. clin. Med. 1957, 49, 331.

14. Maggi, G. Personal communication.

15. Leonards, J. R., B. R. Landau, J. W. Craig, F. I. R. Martin, M. Miller, and F. M. Barry. Regulation of blood glucose concentration: hepatic action of insulin. Amer. J. Physiol. 1961, 201, 47.

16. Madison, L. L., and R. H. Unger. Unpublished observations.

17. Berson, S. A., R. S. Yalow, A. Bauman, M. A. Rothschild, and K. Newerly. Insulin- $\mathrm{I}^{131}$ metabolism in human subjects: demonstration of insulin binding globulin in the circulation of insulin treated subjects. J. clin. Invest. 1956, 35, 170.

18. Mirsky, I. A., and G. Perisutti. The inactivation of insulin by liver slices of the rat. Endocrinology 1953, 52, 698.

19. Bergman, H. C., and D. R. Drury. Effect of feeding and fasting on sugar utilization of eviscerated rabbits. Proc. Soc. exp. Biol. (N. Y.) 1937-38, 37, 414.

20. Skinner, W., and L. L. Madison. A further role of epinephrine and glucagon in producing their counterregulatory response to hypoglycemia. Clin. Res. 1960, 8, 60.

21. Cahill, G. F., Jr., J. Ashmore, A. E. Renold, and A. B. Hastings. Blood glucose and the liver. Amer. J. Med. 1959, 26, 264.

22. Tyberghein, J. M. Action du glucagon sur le metabolisme des protéines. Arch. int. Physiol. 1953, 61, 104.

23. Salter, J. M., I. W. F. Davidson, and C. H. Best. The pathologic effects of large amounts of glucagon. Diabetes 1957, 6, 248.

24. Izzo, J. L., and S. R. Glasser. Comparative effects of glucagon, hydrocortisone, and epinephrine on protein metabolism of the fasting rat. Endocrinology 1961, 68, 189. 